\title{
Folk Literature for Children and Youth from The Perspective of The Malay Mind
}

Arba'ie Sujud, Nik Rafidah Nik Muhamad Affendi, Nor Azuwan Yaakob and Zuraini Jusoh

To Link this Article: http://dx.doi.org/10.6007/IJARBSS/v11-i11/11308

DOI:10.6007/IJARBSS/v11-i11/11308

Received: 11 September 2021, Revised: 14 October 2021, Accepted: 26 October 2021

Published Online: 20 November 2021

In-Text Citation: (Sujud et al., 2021)

To Cite this Article: Sujud, A., Affendi, N. R. N. M., Yaakob, N. A., \& Jusoh, Z. (2021). Folk Literature for Children and Youth from The Perspective of The Malay Mind. International Journal of Academic Research in Business and Social Sciences, 11(11), 2012-2019.

Copyright: (C) 2021 The Author(s)

Published by Human Resource Management Academic Research Society (www.hrmars.com)

This article is published under the Creative Commons Attribution (CC BY 4.0) license. Anyone may reproduce, distribute, translate and create derivative works of this article (for both commercial and non0-commercial purposes), subject to full attribution to the original publication and authors. The full terms of this license may be seen at: http://creativecommons.org/licences/by/4.0/legalcode

Vol. 11, No. 11, 2021, Pg. $2012-2019$

Full Terms \& Conditions of access and use can be found at http://hrmars.com/index.php/pages/detail/publication-ethics 


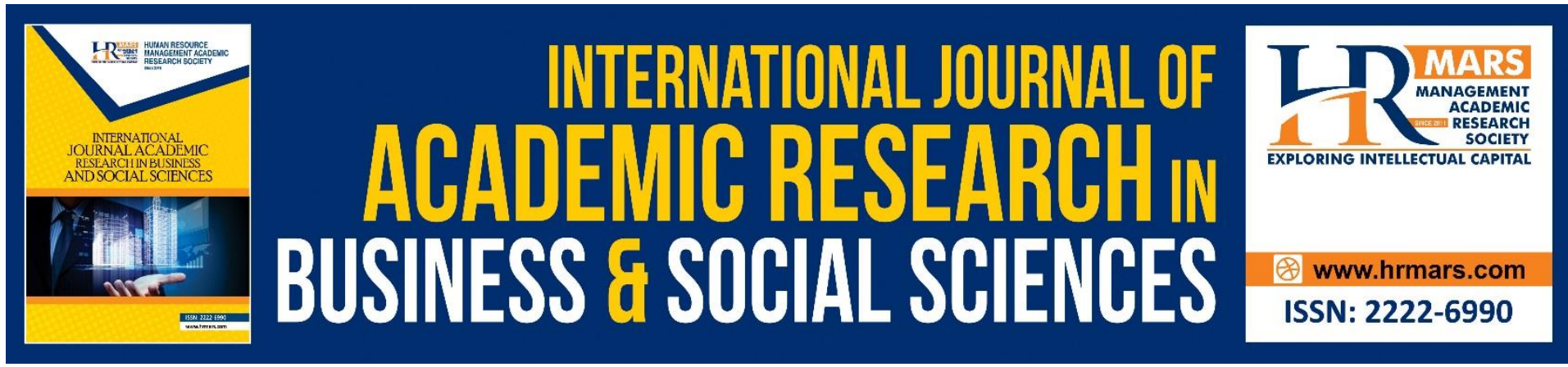

\title{
Folk Literature for Children and Youth from The Perspective of The Malay Mind
}

\author{
Arba'ie Sujud, Nik Rafidah Nik Muhamad Affendi, Nor Azuwan \\ Yaakob and Zuraini Jusoh \\ Malay Language Department Faculty of Modern Languages and Communication
}

Universiti Putra Malaysia

\begin{abstract}
Folk tales need to be exposed to children and adolescents. In the Malay folk literature, it was clear that the Malay worldview was reflected. The Malay worldview of life emphasized good relations between human beings, nature, and the environment. This statement proved that the elements found in folk tales could be shared with children and adolescents. Children and teenagers could learn from reading. At this stage of development, children and adolescents began to learn what is right and what is wrong. The objective of this study was to identify the Malay mind found in Children's and Adolescent Folk Literature and to analyze the Malay mind found in Children's and Adolescent Folk Literature. The findings of the study showed that the folk tales discussed symbolized the wisdom of the mind of the traditional Malay community. Subtly made remarks using natural resources opened the minds of the audience to think.
\end{abstract}

Keywords: Malay Mind, Folktales, Children, and Adolescents

\section{Introduction}

Children's literature begins with oral traditions such as children's songs through poetic songs and folktales. In this case, what is meant by folk literature for children is that which has been modified according to the suitability for children. The content of the story and writing techniques are simplified so that the message contained in the story can be conveyed to the child audience. Although the folktales are presented for the general public, they attract the interest of children. In the history of children's literature, Hadijah (2006: 3) also believes the early development of children's literature in the Malay community, such as literature for children can be the effect of oral literary tradition. Oral literature or better known as folk literature, although intended specifically to feed the souls of the adult community members, has become widespread and gain the interest of children and adolescents.

The term folk literature is often equated in meaning with oral traditions other than folklore. However, according to Mohd. Taib, folk literature has a narrower meaning compared to the oral tradition (Taib, 1972a: 159). Folk literature is often seen as something dead or extinct or at least a legacy or relic of the past (Taib, 1972a: 159). Its use is also limited to oral stories and traditional stories that are commonly told as bedtime stories to children (Taib, 1976a: 8). 
In this case, Sidin (2004: 19) stated that folktales are passed down from one generation to another through oral tradition. In the process, it undergoes additions and modifications in line with current and local situations. Folktale, in this case, has no real author. Folktale in most cultures was originally not solely addressed exclusively to the children. In the oral tradition, the storyteller is surrounded by adults and children as his audience. In the process of obtaining story materials for publication, folktales were rewritten for an audience of children and adolescents. Based on the statement, the question arises whether folklore is suitable to be used as reading material for children and adolescents today.

In Malay folk literature, the Malay worldview is clearly reflected. Malay worldview is concerned about good relations between people, between man and the natural world, and between man and supernatural or metaphysical world. That is why in folk literature, there are all kinds of metaphors that contain the elements of education and example. All this proves how traditional society lives in a community. The traditional society also seems to be inseparable from its natural world (Othman, 1991: 12). This statement proves that the elements found in folk tales can be shared with children and adolescents. Children and adolescents can slowly get to know the world around them. At this stage of development children and adolescents begin to learn what is right and what is wrong.

Correspondingly, according to Kohlberg's Moral Theory, at this stage, the child begins to practice kindness, honesty, loyalty, obedience, and various other types of moral aspects, even if he/she does not know the true meaning of morality (Mahmood, 2001: 2007). Notably, children and adolescents cannot live alone without guidance. They need the guidance of the surrounding community to learn, find out, and recognize the world around them. Therefore, suitable reading material can be used as a guide or information-sharing tool. They may glean in them, an experience that may not be available in the world of reality. The stories found in folktales are not to blame any party but simply to leave as a mirror or reflection and build a life experience, hoping it can be a treasure trove of wisdom that helps to understand a moment of childhood. If they stumbled upon a mirror, their faces are reflected, if they fall in the middle of the road, a life experience is built. Perhaps, one can 'catch' a lesson, 'taste' the beauty, and 'pluck' a pearl of wisdom.

Folktales insert a lot of Malay intellect or thought or mind. The literal and implicit elements are conveyed in a subtle way. According to Abdul (2006: 17), studies in the field of parapsychology have proven that by using the mind, humans can communicate with others without any organic tools, and this is what is called telepathy. It has also been proven, the mind can see something far away, and this is what is called clairvoyance. In addition, it has been shown that the mind can influence the behavior of an object, and this is what is called psychokinesis. Based on the above statement, the Malay mind found in folktales continues to thrive. It is 'eternal'. The traditional Malay society has foresight, the message contained in the stories can be received from one generation to another and the values can be a guide of life.

The objective of this study was to:

1. Identify the Malay mind found in Children's and Adolescent Folk Literature

2. Analyze the Malay mind found in Children's and Adolescent Folk Literature 
The research material narrated in this study were Seuncang Padi (A bag of Rice), Tuhan yang Maha Adil (God is the Most Just), Padi Berbuah Emas (Paddy Bearing Gold) and Pokok Pisang Pokok Durian (Banana Tree Durian Tree).

\section{Psychological Approach}

Cognition is an intellectual process. This means that cognition involved higher mental processes such as thinking, speaking, storing information in memory, and using stored information to reason, making various decisions, and solving problems. Cognition is also an active process. All information obtained from the environment is transformed, stored, and actively used in the process of cognition. All this information is obtained through the sensory system. It is then organized and interpreted by the perceptual system as well as the mind system.

The information that has been processed is then stored and retrieved from memory. It is used in various forms such as problem-solving, decision-making, and many others. In addition, cognition is a process that has specific functions. Each process has a specific purpose. For example, we think because there is something we need to understand more about. We use language to communicate with others. The problem we face is solved so that it does not disturb the harmony of our lives. In other words, cognition is used in all aspects of daily life (Mahmood, 2001: 173).

In this study context, the researcher will use cognition theory as the foundation of the study. Therefore, in this study, the researcher will examine folk tales from two aspects, namely the paradigm shift of the Malay mind and applying cognition in daily life that can lead to the process of thinking (mind) and problem-solving.

\section{Findings}

\section{The Shift of Negative to Positive Thinking}

Seuncang Padi (A pouch of Rice) is a folk tale from the state of Pahang. Preliminary research suggests this story is suitable for children and adolescents. In this story, children and adolescents can assess the way thinking affects action. The self-development of individuals is closely related to their minds. This story clearly shows the change of attitude from a lazy to a diligent society. This case shows positive thinking will lead to positive action and a positive result. This is the element that needs to be applied to children and adolescents.

In this story, the traditional Malay community presents a character of an old man who has managed to advise both husband and wife, the lazy character of the community with subtle and simple words but loaded with meaning, who managed to change their attitude from lazy to diligent. This subtle and modest utterance can be seen in the passage below.

"In this pouch, there is something magical, it can make you rich", said the old man. He gave the bag to the husband.

"Tomorrow morning, sprinkle the contents of this bag in the backyard. You will surely be rich soon," said the old man again. He asked for permission to leave.

(Seuncang Padi: 10) 
'Something magical' had caused the couple to think it was gold but they were disappointed when they found the contents of the bag was dried paddy seed. However, because the subtle speech is accompanied by words of advice that give hope to the couple to become rich can be accepted by the lazy husband and wife. Finally, they also managed to live happily and were no longer shackled by poverty.

In this case, the character of the old man does not even bring up the lazy attitude of the couple but seems to tell them to look forward to changing their destiny. In an easy but hopeful tone, born from the observation of the plight of the couple. Here, the process of cognition that involves high mental processes such as thinking and language can be seen that can lead to a shift in the Malay paradigm from negative to positive. 'A pouch of rice' has its own symbolism. 'A pouch of dried paddy seed' which is considered worthless, eventually brings wealth to the husband and wife after working on it.

Meanwhile, in the story of Padi Berbuah Emas (Paddy Bearing Gold), the story of a young man who at first was greedy, but turned into a generous one can be traced. In the early stages, Kasan was angry because his rice was eaten by sparrows. He was reprimanded by an old woman. This can be seen in the passage below:

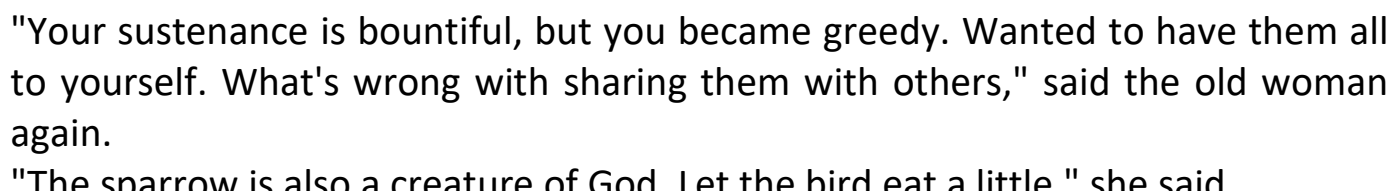

"The sparrow is also a creature of God. Let the bird eat a little," she said.

(Padi Berbuah Emas:18)

The reprimand gave awareness to Kasan to be generous. He

was no longer angry when the sparrows ate his rice. In this case, cognition processes that involve high mental processes such as thinking and language can be detected, which can lead to a shift in Kasan's paradigm from negative to positive.

Positive thinking has a positive effect. Kasan saw the rice that had been eaten by sparrows turned to gold. 'The leftovers of the paddy eaten by sparrows' is symbolic of the bountiful sustenance due to being generous and not greedy. The event opened the minds of children and teenagers to be generous and not greedy in the real world.

In this regard, Atan (1984: 52) has said that when children have reached the age of eleven or twelve years, they have entered the thinking stage of formal processing. This stage is the highest level of thinking that human beings can attain. In this stage, the child's mind is freed from concrete objects. They can use symbols and rules and think effectively. Therefore, the folk tale from Pahang also attracts the attention of children and teenagers even though the story is actually for the general public.

\section{Nature in Malay Thought}

Meanwhile, in the story of Tuhan yang Maha Adil (God the Most Just), the message to be conveyed by the traditional community is the same as the story Seuncang Padi (A pouch of Rice), which is the 'effort will lead to success'. However, the way it is presented clearly shows the process of cognition which involves high mental processes that is related to the thinking 
of society at that time. In this story, images of nature are used in applying cognition in daily life. This story tells of a young girl named Lela who has no purpose in life. She often complained and blamed that "God is not fair". For example, she blamed the pumpkins in the vegetable garden for not matching the stems.

Apart from the pumpkin tree, she also blamed the keranji tree (Dialium indum) for its abundant fruit. According to Lela again, "Yes, God is not fair! Should a tree be so big, the fruit be very small? It's not fair, it's not fair!" said Lela. She sighed as she sat leaning against the tree trunk. Just then, suddenly a keranji fruit fell on her head. She picked up the keranji fruit while looking up. She looked at the branches of the keranji tree. "Hmm, if the keranji fruit is as big as a pumpkin and falls on my head just now, it could break my head! Fortunately, the keranji fruit is small" said Lela.

(Tuhan yang Maha Adil: 63)

Only after the event did she realize and acknowledge "God is Just". This can be seen in the statement below.

"Yes, God is just. Fair. Everything that God made, including the tree and its fruit, certainly has its wisdom", said Lela. She learned a lesson from the incident. So is my life, if I work hard, I will be happy, I get a lot of sustenance like everyone else. From today, I must work", she said.

(Tuhan yang Maha Adil: 63)

Next, the story of Pokok Pisang Pokok Durian (Banana Tree Durian Tree). This story teaches children not to be arrogant. An example can be seen when a durian tree insults the banana tree that was cut down by its owner. This can be traced in the passage below:

"Try to look at me, my trunk is strong, hard, and tough. Your master is powerless to cut me. Every year I bear the fruit. My fruit is fragrant and many people like them. No one dares to touch me", said the durian tree arrogantly.

(Pokok Pisang Pokok Durian: 166)

Soon, a storm passed. Finally, the durian tree fell on the side of the banana tree. He cried because he did not expect to suffer the same fate as the banana tree even though due to different causes. The durian tree is ashamed of the banana tree. The simple storyline is accompanied by cause and effect making it easier for children and teenagers to understand the story. The events in the four stories provide space for children and adolescents to think and take lessons from the events. This scenario also shows that there is a process of cognitive application in daily life. This process occurs if a society including children and adolescents thinks and takes comparisons from God's creation on this earth.

\section{Conclusion}

The results of the study show that the four stories discussed symbolize the wisdom of the traditional Malay mind. Criticism that is made subtly by using natural resources opens the minds of the audience to think. Natural elements are used as the material of the story. The 
wisdom of the Malay mind at that time stand out as they succeeded in making the paradigm shift of the people's minds in a subtle way in accordance with the Malay culture. In fact, the stories in the folk tales always stimulate people's thinking, including children and adolescents. Here, there is the application of cognition in everyday life. This study can contribute to the world of childhood and youth literature. The selection of quality story material for children and adolescents can be used as a guideline for them to continue their life and teach them to think critically to solve problems.

\section{References}

Abdul, F. H. (2006). Tenaga dan Keremajaan Minda. Kuala Lumpur: Utusan Publications \& Distributors Sdn. Bhd.

Abdullah, S. A. (1966). Peranan Pejabat Karang Mengarang Dalam Bidang-Bidang Pelajaran Sekolah-Sekolah Melayu dan Kesusasteraan di Kalangan Orang Ramai. Kuala Lumpur: Dewan Bahasa dan Pustaka.

Atan, L. (1984). Bahan-bahan Tempatan Untuk Penciptaan Sastera Kanak-kanak di Malaysia dalam Sekitar Sastera Kanak-kanak dan Remaja. Kuala Lumpur: Dewan Bahasa dan Pustaka.

Hadijah, R. (2006). Peranan dan Perkembangan Sastera Kanak-kanak. Kuala Lumpur: Dewan Bahasa dan Pustaka.

Jas, L. S. J. (2001). Sastera Kanak-kanak dan Remaja.Kuala Lumpur: Dewan Bahasa dan Pustaka.

Mahmood, N. M. (2001).Pengantar Psikologi. Kuala Lumpur: Dewan Bahasa dan Pustaka.

Mana, S. (2004). Proses Penulisan Kreatif. Johor: EDN Media.

Sidin, M. A. I. (2005). Perkembangan Sastera Kanak-kanak di Malaysia. Shah Alam: Cerdik Publications Sdn. Bhd.

Misran, R. (2006). Isu Pendidikan dan Pembangunan Menerusi Novel. Bangi: Universiti Kebangsaan Malaysia.

Kasim, M. I. (2001). Kesusasteraan Kanak-kanak dan Remaja. Selangor: Universiti Putra Malaysia

Taib, M. O. (1972a) Laporan Naskhah-naskhah dan Alatan-alatan Budaya Melayu di Beberpa Pusat Pengajian di Great Britain dan Jerman Barat dalam Nusantara 1, Januari.

(1976b). Pendokumentasian Sastera Rakyat dan Sastera Daerah Malaysia. Dewan Sastera Julai, 39-41.

Raudah, N. H. S. (2006). Falsafah Diri Remaja dalam Novel Remaja Melayu.Kuala Lumpur. Dewan Bahasa dan Pustaka.

Othman, P. (1984). Sekitar Sastera Kanak-kanak dan Remaja. Kuala Lumpur: Dewan Bahasa dan Pustaka.

(1989). Sastera Remaja Ditinjau daripada Beberapa Perspektif. Kuala Lumpur:

Dewan Bahasa dan Pustaka.

(1988). Tanggapan Terhadap Kesusasteraan Remaja. Kuala Lumpur: Dewan Bahasa

dan Pustaka.

\& Aripin, S. (Ed).(2008). 366 Cerita Rakyat Malaysia. Kuala Lumpur: Utusan Publications dan Distributors Sdn Bhd.

Rahman, S., \& Nurazmi, K. (1984). Kesinambungan Sastera Melayu: Puisi dan Prosa. Kuala Lumpur: Karya Bistari Sdn. Bhd.

Sawyer, W., \& Diana, E. C. (1997). Membesar Bersama Kesusasteraan. Kuala Lumpur Dewan Bahasa dan Pustaka. 
INTERNATIONAL JOURNAL OF ACADEMIC RESEARCH IN BUSINESS AND SOCIAL SCIENCES Vol. 11, No. 11, 2021, E-ISSN: 2222-6990 @ 2021 HRMARS

Zalila, S., \& Jamilah (Ed). (1993). Kesusasteraan Melayu Tradisonal. Kuala Lumpur: Dewan Bahasa dan Pustaka. 